\title{
NUMERICAL INSIGHTS INTO STRESS REDISTRIBUTION IN PROTECTED SEAM MINING WITH COAL PILLARS AND AN APPLICATION TO METHANE CONTROL
}

\author{
Fulian $\mathrm{HE}^{1,2)}$, Ruojun $\mathrm{ZHU}^{3)}$ and Hengzhong $\mathrm{ZHU}^{1,2)}$ * \\ ${ }^{1)}$ School of Energy and Mining Engineering, China University of Mining and Technology (Beijing), Beijing 100083, China \\ ${ }^{2)}$ Beijing Key Laboratory for Precise Mining of Intergrown Energy and Resources, China University of Mining and Technology (Beijing), \\ Beijing 100083, China \\ ${ }^{3)}$ Zhongtian Hechuang Energy Limited Liability Company, Ordos, Inner Mongolia 017000, China \\ *Corresponding author's e-mail: z_hz99@163.com
}

\begin{tabular}{l} 
ARTICLE INFO \\
\hline Article history: \\
Received 15 November 2018 \\
Accepted 13 March 2019 \\
Available online 24 April 2019 \\
\hline
\end{tabular}

Keywords:

Protected seam mining

Coal pillar

Stress redistribution

Methane control

Divisional management strategy

\begin{abstract}
This paper identifies the stress redistribution of protected seams under the influence of coal pillars and a divisional management strategy for methane control. A coal pillar that is reserved in the protective seam greatly affects the abutment stress, the O-shaped circle's evolution and the stress distribution. The strain-soften model was conducted using FLAC3D numerical analysis software to investigate the stress redistribution in the protected seam mining process. The results show that the abutment stress reaches a maximum value of 1.25 times the original stress when a protected seam coal face lies in the center of the coal pillar's affected zone. The O-shaped circle is divided into two parts by the coal pillar, and its developmental width is closely associated with the protected seam mining stage and the developmental height of the "three zones", especially the fractured zone. The stress redistribution of protected seam is rarely affected by the coal pillar when the distance is greater than $26 \mathrm{~m}$. Both the total increased stress belt of the coal pillar affected zone and the total decreased stress belt of the other zones along the vertical direction significantly influence the methane migration. We propose a divisional management strategy that supplies a theoretical basis and technical guidance for methane control.
\end{abstract}

\section{INTRODUCTION}

Due to rapid and sustainable economic development, China has already become one of the largest coal-dependent energy-consuming countries in the world. According to "The 13th Five-Year Plan for Economic and Social Development of China (20162020 )", the proportion of coal will decrease from $64 \%$ to less than $58 \%$ with respect to the total energy consumption. However, it still holds the leading role due to China's energy production since the country is rich in coal but poor in oil and gas. Underground coal mines account for more than $95 \%$ in China, and $17.6 \%$ of state-owned coal mines experience coal and gas outbursts. Gas explosions, coal and gas outbursts and other gas disasters have seriously threatened coal mines' safety in recent years (Zhu et al., 2017).

Prevention strategies for coal and gas outbursts such as protective seam mining, gas drainage, blasting to loosen rock, hydraulic flushing and water injection technology have been widely used in order to increasemining safety. As a kind of governance strategy for coal and gas outbursts, protective seam mining is the most effective way for reducing or eliminating the outburst risk, and especially has priority in multiseam mining (Jin et al., 2016). The in situ stress will decrease after the protective seam is mined. Accordingly many fractures or interlayer cracks occur in the protected seams and surrounding rock layers (Xiong et al., 2015). As a result, the protected seam permeability significantly improved, the methane begins to desorb and its flowing ability is also enhanced. When adopting an effective method for gas extraction, the gas pressure and gas content of protected seams will obviously decrease. Consequently, the outburst zone will also be eliminated, and afterwards the protected seam is made safe for mining (Li, 2006).

For the purpose of insulating against underground water and protecting surface buildings and underground roadways in the mining process, some coal pillars must be reserved. Especially, barrier pillars for protecting the main tunnels, haulage roadways and ventilation roadways have become universal. However, highly concentrated stress is also accordingly generated by the barrier pillar. The highly concentrated stress will spread, and then affect the stress of the surrounding rock layers (Zhu et al., 2014). Several coal and gas outburst disasters have occurred because of barrier pillars in recent years. More than twenty people died in these related 
(a)

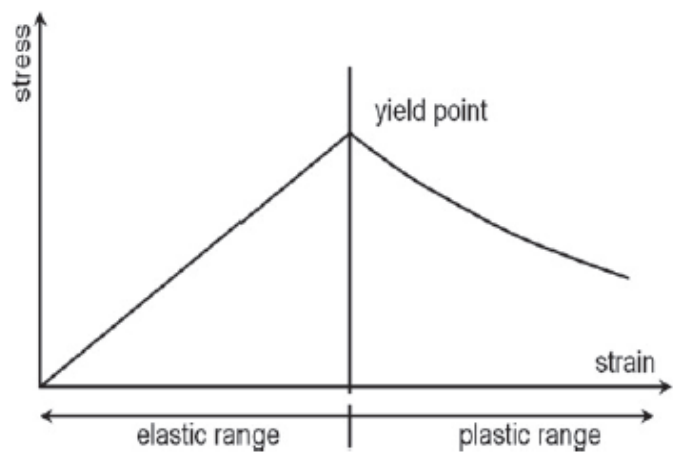

(b)

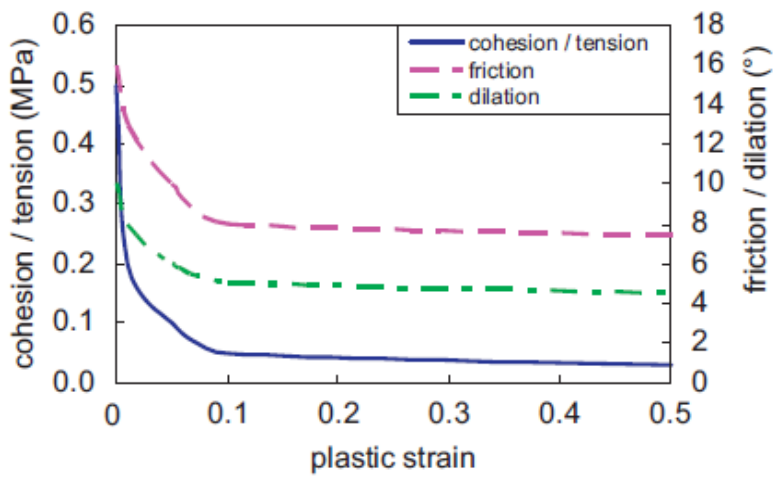

Fig. 1 The relationship between the stress and the strain: (a) the sketch of the stress-strain curve and (b) the relationship between the plastic strain and coal strength.

disasters. Previous studies have indicated that these disasters mostly taken place near the barrier pillars (Jiang et al., 2017). Researchers have found various results that are favorable for understanding what the coal pillar generates, including theoretical analysis, field investigations and empirical derivation (Singh et al., 2011; Wilson, 1983; Yu et al., 2016). However, most of these studies focused on the stability, strength, loading state, design method and failure behavior of coal pillars (Ashok Jaiswal and Shrivastva, 2009; Bertuzzi et al., 2016). These findings mainly focus on roadway driving along the gob, room and pillar mining, roof movement during depillaring and other areas (Cheng et al., 2010; Jayanthu et al., 2004; Sherizadeh and Kulatilake, 2016; Wang et al., 2013). In the process of protective seam mining, the released methane that comes from the protective seam and adjacent coal seam may rush into the working face, and then cause a methane overrun. Furthermore, the gas pressure and gas content still re main relatively high in the highly concentrated stress zone that is generated by the coal pillar. It is also shown that the released methane flowing performance and the protected scope are determined by the stress redistribution (Yang et al., 2014). In particular, understanding the stress redistribution in the process of protective seam mining is a key that enables mining engineers to predict and prevent coal and gas outbursts. Although many studies have been undertaken to understand the stress redistribution, few studies have considered the protective seam that is related to the coal pillar under the condition of multiseam mining. Therefore, a full understanding of the stress redistribution is essential for effective methane control.

The various geological conditions of coal seams cause great difficulty in studying stress redistribution if we merely adopt field measurements or laboratory experiments. Thus, other methods such as numerical simulations have been used in order to acquire the results of stress redistributions, and thus they can be a good choice for this study. By using strain-softening constitutive model based on the FLAC3D numerical simulation software, this paper systematically studies how the abutment stress changes in the dynamic process of protective seam mining under the influence of coal pillars, how the O-shaped circle evolves, how the stress redistribution is affected by the coal pillar as the working face advances and how we control the methane according to the division of the protected scope.

\section{NUMERICAL MODEL ESTABLISHMENT}

The FLAC3D numerical simulation analysis software provides an important visual method to study the loading, deformation and stability of various materials and structures, especially fit for the progressive failures and nonlinear large deformations of rock masses in mining engineering (Itasca consulting group, 2012). It covers eleven kinds of constitutive models, which are the following: one null model, three elastic models and seven plastic models. Mining operations will cause rock mass deformations and the rock mass strength will decrease. After the stress exceeds the peak strength of the rock mass, the rock mass experiences increasing degradation as the deformation continuously increases. The rock mass can be defined as an elastic-plastic material and it experiences strain-softening after it is damaged. Previous studies have certified that the results of numerical simulations based on the strain-softening model are more aligned with the field investigation (Corthesy and Leite, 2008; Edelbro, 2009; Lee and Pietruszczak, 2008), and so the strain-softening model was chosen as a solution in this study.

It can be discovered that the strain is composed of elastic and plastic, as shown in Figure 1(a). The stress linearly increases as the elastic strain increases while it decreases nonlinearly as the plastic strain decreases after the rock mass is damaged beyond the yield point (Itasca consulting group, 2012). The rock mass experiences strain-softening at this moment. Hence, the friction angle, cohesion, dilation angle and tensile strength gradually soften as the plastic strain increases. Figure 1(b) shows that the strength decreases much faster in the beginning. 
Table 1 Coal and rock mass properties.

\begin{tabular}{lccccccc}
\hline Lithology & $\begin{array}{c}\text { Density } \\
\left(\mathrm{kg} / \mathrm{m}^{3}\right)\end{array}$ & $\begin{array}{c}\text { Bulk } \\
\text { modulus } \\
(\mathrm{GPa})\end{array}$ & $\begin{array}{c}\text { Shear } \\
\text { modulus } \\
(\mathrm{GPa})\end{array}$ & $\begin{array}{c}\text { Friction } \\
\text { angle } \\
\left({ }^{\circ}\right)\end{array}$ & $\begin{array}{c}\text { Cohesion } \\
(\mathrm{MPa})\end{array}$ & $\begin{array}{c}\text { Tensile } \\
\text { strength }(\mathrm{MPa})\end{array}$ & $\begin{array}{c}\text { Dilation } \\
\text { angle } \\
\left({ }^{\circ}\right)\end{array}$ \\
\hline Coal seam & 1350 & 1.15 & 0.70 & 18 & 1.20 & 0.74 & 10 \\
Fine grained & 2550 & 3.85 & 2.80 & 28 & 2.80 & 3.20 & 10 \\
sandstone & 2200 & 1.80 & 1.50 & 22 & 2.20 & 1.50 & 10 \\
Clay stone & 2700 & 22.6 & 11.5 & 38 & 10.5 & 7.80 & 10 \\
Maokou limestone & & & & & & &
\end{tabular}

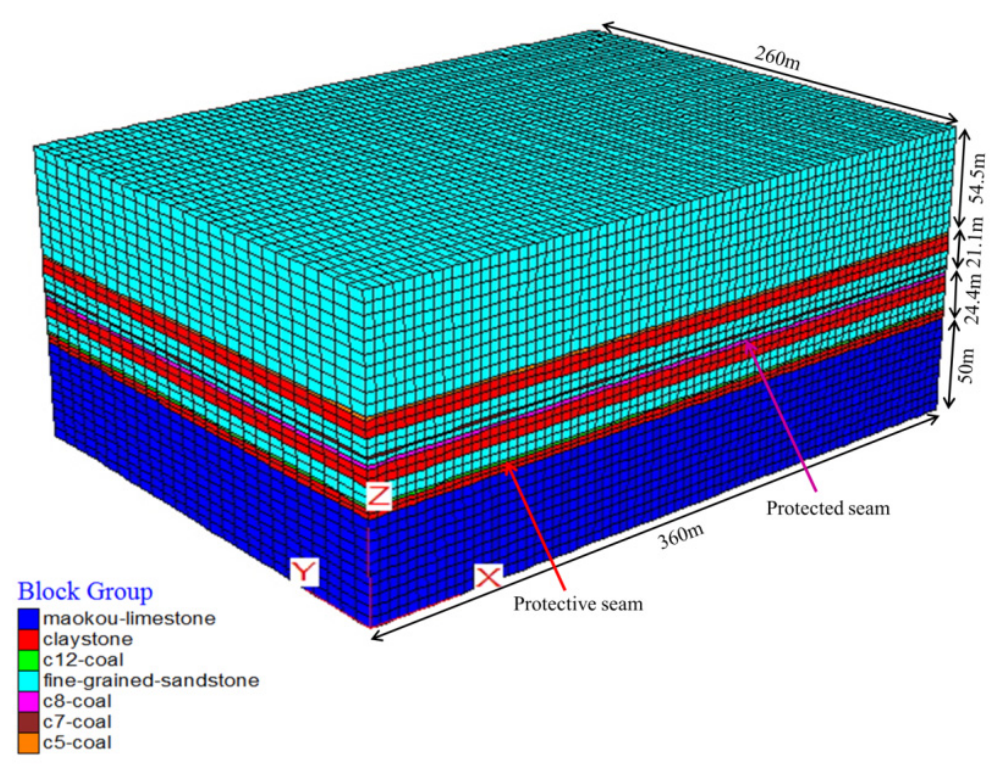

Fig. 2 Numerical simulation model for this study.

A numerical model with a fixed horizontal displacement at four sides and a fixed vertical displacement at the bottom was established based on the stratigraphic condition of the Huahang coal mine in Guizhou province, southwestern China. The model covers an area of $360 \mathrm{~m} \times 260 \mathrm{~m}, 150 \mathrm{~m}$ in height with 65520 zones and 70956 grid-points (Fig. 2). The initial properties of the rock mass and coal are listed in Table 1, which were determined based on the geological survey report and the rock mechanics experimental test in the laboratory. There are four coal seams, which are $\mathrm{C} 12, \mathrm{C} 8, \mathrm{C} 7$ and $\mathrm{C} 5$ with the thicknesses of $1.3 \mathrm{~m}, 2 \mathrm{~m}, 1 \mathrm{~m}$ and $1.5 \mathrm{~m}$, respectively. The $\mathrm{C} 8$ coal seam has the greatest coal and gas outburst risk according to the measurement of the gas content. The $\mathrm{C} 12$ coal seam was mined first as the lower protective seam in order to reduce or eliminate the outburst risk of the $\mathrm{C} 8$ coal seam. In the mining process of the $\mathrm{C} 12$ coal seam, the coal pillar protected the 18\# uphill tunnel in order to satisfy the mining system's requirements. The strike length, inclination length and mining height of the $\mathrm{C} 12$ coal seam working face are $280 \mathrm{~m}, 180 \mathrm{~m}$ and $1.3 \mathrm{~m}$, respectively. The stress change after each excavation cycle was recorded by monitoring the lines that were arranged in the roof of the $\mathrm{C} 12$ coal seam.

\section{RESULTS AND DISCUSSION}

\subsection{ABUTMENT STRESS CHANGES OF PROTECTED SEAM}

The stress of the rock mass will be redistributed as the working face advances. As a kind of loading, the overlying strata weight acts on the coal face and causes the tangential stress to increase. The increased tangential stress is called the abutment stress and has a peak value of $2 \sim 4$ times the original stress (Song, 2003). Existing studies have certified that the coal and rock mass in front of the coal face will generate fractures due to the abutment stress changes (Min et al., 2004), and then this behavior will affect the gas flows. Therefore, this calls for a study on the changeable regularity of the abutment stress in the process of protected seam mining for methane control. The change rule of the abutment stress can be studied according to the stress redistribution in the mining stage. When protected seam is mined $20,40,60 \ldots$ and $280 \mathrm{~m}$, respectively, the abutment stress distribution curves that are affected by a $10 \mathrm{~m}$ wide coal pillar are shown in Figure 3. The coal pillar is retained in the middle of the protective seam's working face. For instance, the curve of $20 \mathrm{~m}$ shows the abutment stress distribution when the protective seam is mined $20 \mathrm{~m}$. 


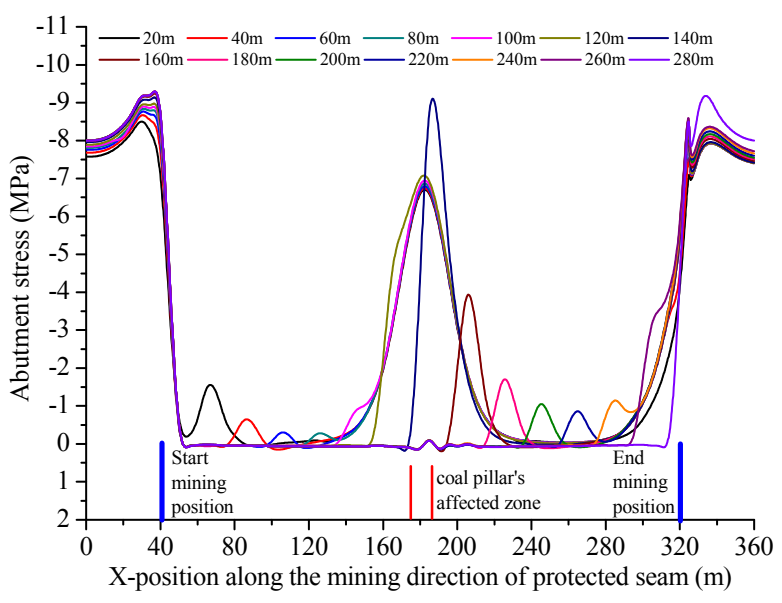

Fig. 3 Abutment stress change of the protected seam at different mining stages.

It can be seen that the abutment stress distribution of the protected seam has its own unique characteristics. The protected seam working face is in the state of stress relief except for the coal pillar's affected zone. The abutment stress has a lower value but its value is large in the coal pillar's affected zone. There is a complex change law for the abutment stress. When the protected seam is mined $20 \mathrm{~m}$, the abutment stress at the coal face is approximately $0.52 \mathrm{MPa}$ while it increases to a peak value of $1.69 \mathrm{MPa}$ approximately $5 \mathrm{~m}$ ahead of the coal face. Then, the abutment stress falls to $0.2 \mathrm{MPa}$ approximately $25 \mathrm{~m}$ in front of the coal face. However, since it is far away from the coal face, the abutment stress rises rapidly because of the coal pillar's effects. The abutment stress reaches a peak value of $6.74 \mathrm{MPa}$ approximately $120 \mathrm{~m}$ ahead of the coal face and then rapidly decreases to $0.14 \mathrm{MPa}$ approximately $170 \mathrm{~m}$ in front of the coal face. When the protected seam is mined $40 \mathrm{~m}, 60 \mathrm{~m}$ and $80 \mathrm{~m}$, respectively, the peak value and distribution area of the abutment stress both progressively decrease. This is mainly because the stress relief zone increases as the gob expands.

When the protective seam is mined $140 \mathrm{~m}$, the abutment stress rapidly grows to $9.9 \mathrm{MPa}$ (1.25 times the original stress). At that moment, the protected seam coal face is right above the coal pillar. In the coal pillar's affected zone, the abutment stress increases sharply under the influence of highly concentrated stress. Therefore, gas predrainage, hydraulic fracturing technology and other measures must be conducted in advance in order to reduce or eliminate the coal and gas outburst risk of the protected seam in this stage. When the protective seam is mined $160 \mathrm{~m}$, the peak value of the abutment stress quickly decreases to $4.5 \mathrm{MPa}$ ( 0.56 times the original stress). Existing studies have proved that the high stress gradient can break the rock mass and coal seam more easily (Alireza and Jing, 2008). Consequently, the coal is broken more easily and various fractures will open in this stage, and then the methane releases easily. Hence, gas drainage boreholes should be used in order to excavate the methane earlier and prevent the gas density from overrunning.

Figure 4 shows the three-dimensional abutment stress distribution of the protected seam at the four mining stages of $20 \mathrm{~m}, 140 \mathrm{~m}, 160 \mathrm{~m}$ and $260 \mathrm{~m}$. It is noted that the $\mathrm{x}$-stress represents the horizontal stress along the $x$-direction, the $y$-stress represents the horizontal stress along the y-direction and the $\mathrm{z}$-stress represents the vertical stress along the $\mathrm{z}$-direction. The stress shows the tensile state within $20 \mathrm{~m}$ behind the coal face when the protected seam is mined $20 \mathrm{~m}$. Approximately $10 \mathrm{~m}$ ahead of the coal face, the abutment stress increases rapidly and presents a compressive state. A large amount of gas will inrush into the working face due to the stress state's sudden transformation. Therefore, gas drainage for the gob and strengthened ventilation for the working face should be implemented in this stage in order to prevent the methane from accumulating. Approximately $90 \mathrm{~m}$ ahead of the coal face, the zstress rapidly rises to $7.5 \mathrm{MPa}$ and appears as a singlepeak. The $\mathrm{x}$-stress curve presents a double-peak distribution while the y-stress curve presents a singlepeak distribution.

When the protected seam is mined $140 \mathrm{~m}$ and $160 \mathrm{~m}$, respectively, the gob is in the stress relief state because of the protective effect. However, the stress is in the highly concentrated state under the influence of the coal pillar. If the protected seam possesses coal and gas outburst risk, coal and gas outbursts that are influenced by the highly concentrated stress may happen at this time. Therefore, the stress relief measures must be implemented in advance in order to prevent the coal and gas outbursts. The drilling length of boreholes for gas drainage and stress relief should be greater than $20 \mathrm{~m}$ according to the abutment stress distribution.

\subsection{O-SHAPED CIRCLE'S EVOLUTION}

Key stratum will be failure when the loading exceeded its ultimate strength. Bed separation will firstly occur in the central zone of the gob when the maximal bending moment generates in the central zone. However, after the key stratum has broken initially, the central of the gob gradually presents the compressive state, but the bed separation still exists in the two sides of the gob. After the bed separation has connected with each other along the bedding layer in lateral direction. Morphologically, the bed separation emerges as the O-shaped circle (Song, 2003). Bedding separations and fractures in the O-shaped circle provide paths for gas migration. The gas migrates actively, and then flows into the roadway and working face. On the one hand, a large amount of gas will cause the gas density to overrun. On the other hand, the O-shaped circle is favorable for gas drainage. Hence, it is necessary to study the O-shaped circle's evolution in order to achieve better methane control. 
(a)

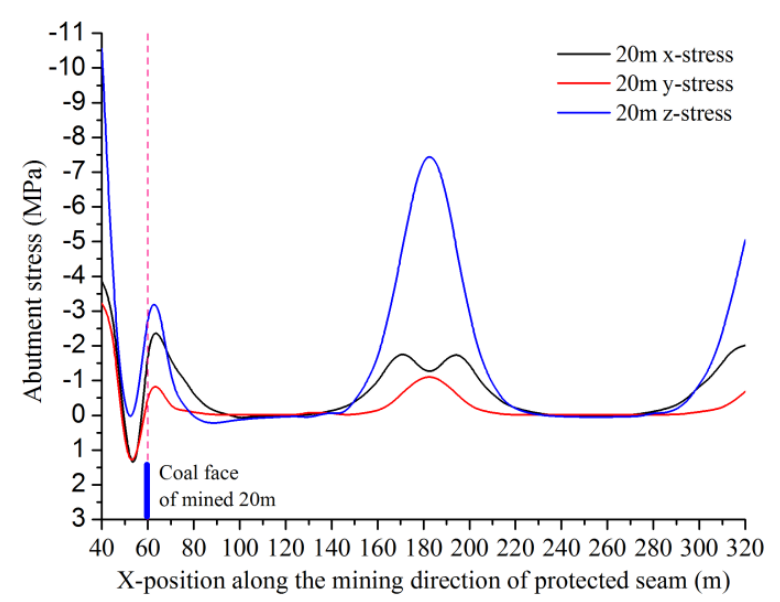

(c)

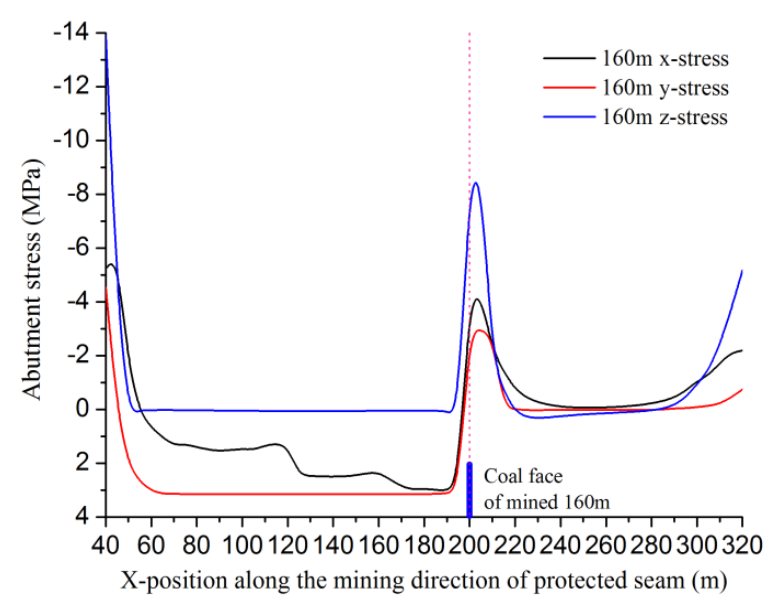

(b)

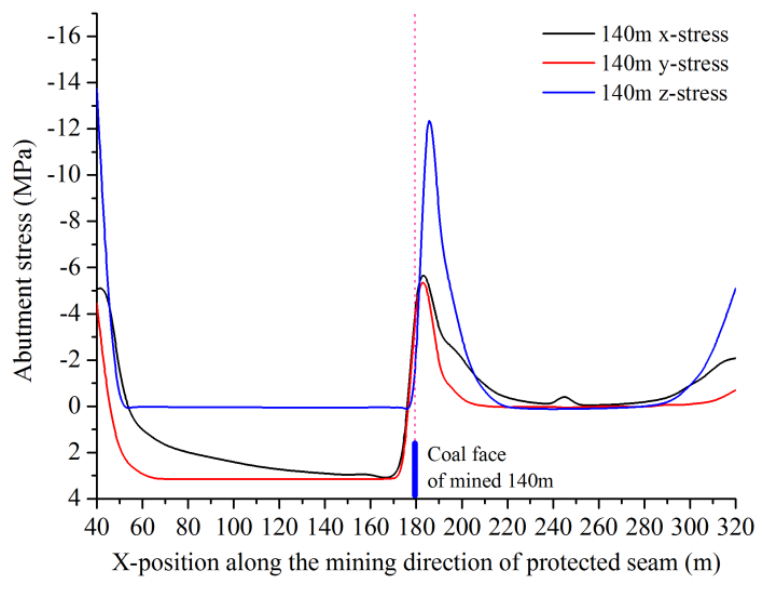

(d)

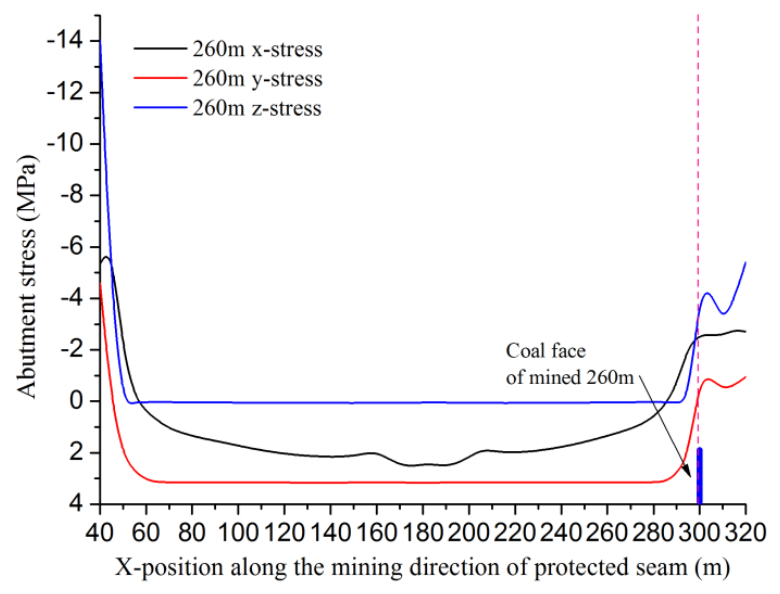

Fig. 4 Three-dimensional abutment stress distribution of four mining stages: (a) $20 \mathrm{~m}$, (b) $140 \mathrm{~m}$, (c) $160 \mathrm{~m}$ and (d) $260 \mathrm{~m}$.

\subsubsection{O-SHAPED CIRCLE'S EVOLUTION DURING THE PROTECTED SEAM MINING PROCESS}

The O-shaped circle's evolution in the four mining stages of $20 \mathrm{~m}, 140 \mathrm{~m}, 160 \mathrm{~m}$ and $260 \mathrm{~m}$ is shown in Figure 5. In the mining stage of $20 \mathrm{~m}$, the O-shaped circle's distribution is symmetrical to the coal pillar's affected zone. The O-shaped circle is generated prior to the protected seam mining because of the protective effect of the protective seam. The roof collapsed and caved continually when the working face was mined $140 \mathrm{~m}$, and then the gob gradually reflects the compressive state. Hence, bedding separations and fractures have closed under the influence of compressive affection. Compared with the mining stage of $20 \mathrm{~m}$, it is obvious that the O-shaped circle's width decreases for the mining stage of $140 \mathrm{~m}$. In these two mining stages, the coal pillar affected width decreases from $18.23 \mathrm{~m}$ to $9.74 \mathrm{~m}$ and the length decreases from $129.1 \mathrm{~m}$ to $93.37 \mathrm{~m}$. It can be seen that the coal pillar's affected zone decreases because of the stress relief effect of the protected seam. The O-shaped circle of the gob has disappeared when the working face is mined $160 \mathrm{~m}$ while the
O-shaped circle in front of the coal face still exists. The O-shaped circle and the coal pillar's affected zone have completely disappeared from the beginning of the mining stage of $260 \mathrm{~m}$.

Visually speaking, the O-shaped circle seems to be a river for gas to flow. The maximum and the minimum distances are $20.34 \mathrm{~m}$ and $11.57 \mathrm{~m}$ from the roadway, respectively. Hence, the bedding borehole's final location in the protected seam should be in the O-shaped circle and the minimum length should be greater than $12 \mathrm{~m}$ in order to acquire better gas drainage. The dip angle and length of the crossing borehole that is drilled in the roadway of the protective seam working face for protected seam gas drainage can be determined according to the interlayer distance and the O-shaped circle's location.

\subsubsection{O-SHAPED CIRCLE'S EVOLUTION AT DIFFERENT DISTANCES ABOVE THE PROTECTIVE SEAM}

Figure 6 describes the O-shaped circle's evolution at different distances of $2.5 \mathrm{~m}, 8 \mathrm{~m}, 15 \mathrm{~m}$, $17.8 \mathrm{~m}, 26 \mathrm{~m}$ and $40 \mathrm{~m}$ above the protective seam. 

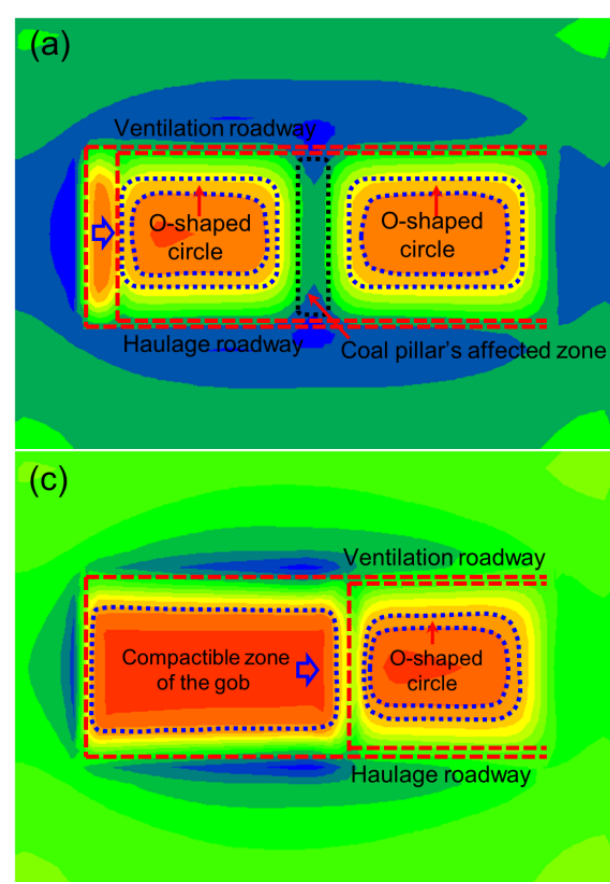

Contour of SZZ

Plane: on
Magac $=0.000 e+000$

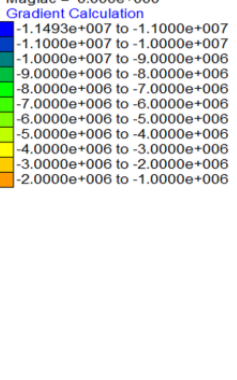

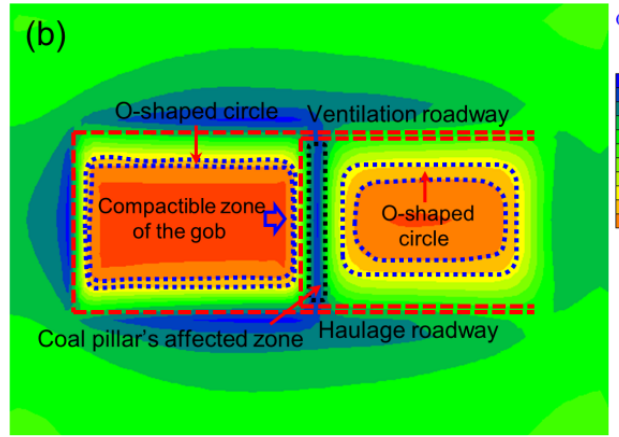

Contour of SZZ

Plane: on
Magtac $=0.000 e+000$

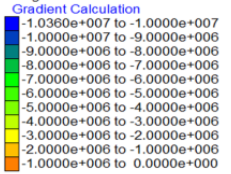

Fig. 5 O-shaped circle evolution during the protected seam mining process: (a) $20 \mathrm{~m}$, (b) $140 \mathrm{~m}$, (c) $160 \mathrm{~m}$ and (d) $260 \mathrm{~m}$.
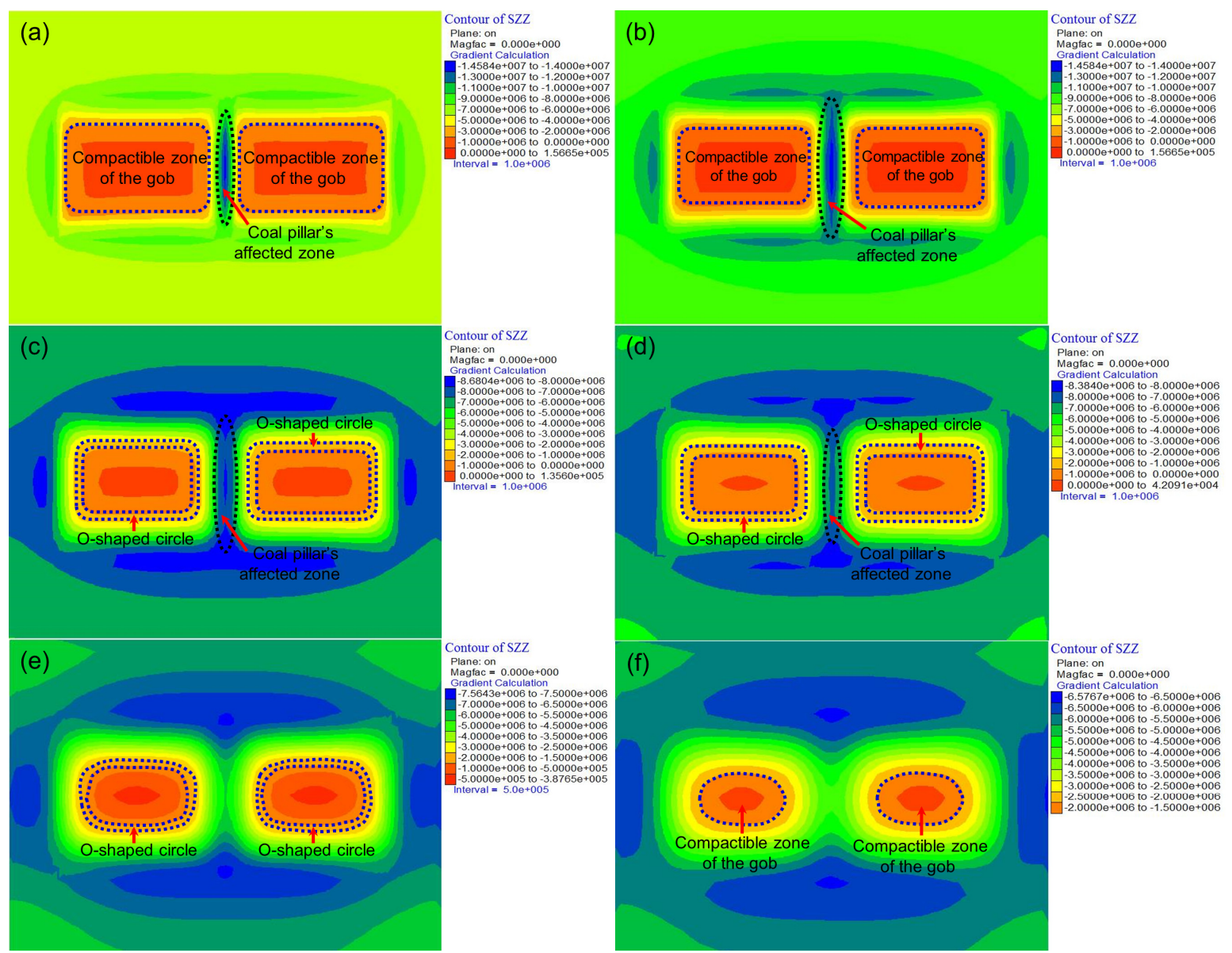

Fig. 6 O-shaped circle's evolution at different distances above the protected seam: (a) $2.5 \mathrm{~m}$, (b) $8 \mathrm{~m}$, (c) $15 \mathrm{~m}$, (d) $17.8 \mathrm{~m}$, (e) $26 \mathrm{~m}$ and (f) $40 \mathrm{~m}$. 


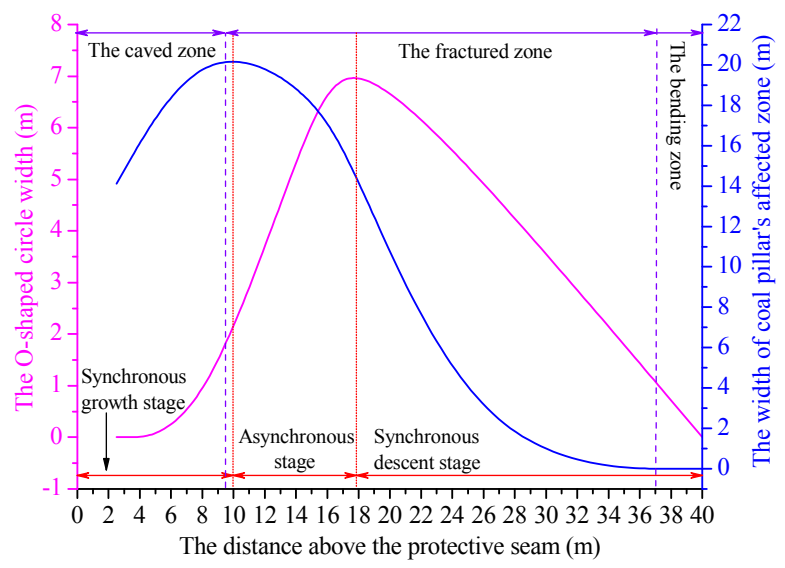

Fig. 7 The change of the O-shaped circle's width and the coal pillar affected width.

There is no development of the O-shaped circle due to the compressive affection of the gob at the distances of $2.5 \mathrm{~m}$ and $8 \mathrm{~m}$. This is mainly because the overlying rock layer within $11.7 \mathrm{~m}$ is in the collapsed state according to the field investigation. This zone is unfavorable for gas drainage. The length and width of the coal pillar's affected zone are $90.9 \mathrm{~m}$ and $14 \mathrm{~m}$, respectively, at the distance of $2.5 \mathrm{~m}$, while they are $116 \mathrm{~m}$ and $21.5 \mathrm{~m}$ when the distance is $8 \mathrm{~m}$. O-shaped circles begin to develop when the distance is $15 \mathrm{~m}$, and they are symmetrical to the coal pillar's affected zone. The coal pillar affected length decreases from $116 \mathrm{~m}$ to $113.5 \mathrm{~m}$ and the width also decreases from $21.5 \mathrm{~m}$ to $18.8 \mathrm{~m}$ in this stage. However, the O-shaped circle's width begins to increase with the average value of $7.5 \mathrm{~m}$ at the distance of $17.8 \mathrm{~m}$, but the length has no significant change. The length and width of coal pillar's affected zone continue to decrease to $93.7 \mathrm{~m}$ and $14.8 \mathrm{~m}$, respectively. What is noteworthy is that the coal pillar's affected zone has vanished, and the O-shaped circle also has disappeared at the distance of $40 \mathrm{~m}$.

Figure 7 describes the change of the O-shaped circle's width and the coal pillar affected width. It is known that the overlying rock layer can be divided into three zones, the caved zone, the fractured zone and the bending zone (Xu, 1999) when the coal seam is fully excavated, each zone has its own specific features. For example, the fractured rock mass is compacted under the influence of overloading in the caved zone while the fractures and bedding separations of the fractured zone are favorable for gas drainage.

According to the calculation result of three zones' distribution, the development height of the caved zone varies from $7.36 \mathrm{~m}$ to $11.76 \mathrm{~m}$ with an average value of $9.56 \mathrm{~m}$. The development height of the fractured zone is $37.2 \mathrm{~m}$ and the bending zone's development height varies from $37.2 \mathrm{~m}$ to $150 \mathrm{~m}$. As shown in Figure 7, the changeof the O-shaped circle's width shows the developmental trend of continuous growth first but decreases gradually afterwards. The O-shaped circle's width is small in the caved zone, but it rapidly grows to $7.47 \mathrm{~m}$ in the fractured zone, and afterwards it decreases continuously when the distance above the protective seam is greater than $17.8 \mathrm{~m}$. The coal pillar affected width also appears with a similar trend compared to the change of the O-shaped circle's width. It also grows gradually in the caved zone while it decreases constantly in the fractured zone and the bending zone. The width reaches the minimum value of $21.56 \mathrm{~m}$ when the distance above the protective seam is $8 \mathrm{~m}$. It is indicated that the O-shaped circle width's and the coal pillar affected width are closely related to three zones' distribution.

The development stages can be divided into the synchronous growth stage, the asynchronous stage and the synchronous descent stage according to the comprehensive law of the O-shaped circle's width and the coal pillar affected width. Both the O-shaped circle's width and the coal pillar affected width are increasing in the synchronous growth stage, decreasing in the asynchronous stage, and decreasing in the synchronous stage. We should take the synchronous stage as the key point in this study. The boreholes for gas drainage and stress relief should be located in the distribution zone of the synchronous stage.

\subsection{STRESS SPATIAL DISTRIBUTION CHARACTERISTICS}

\subsubsection{STRESS DISTRIBUTION ALONG X-DIRECTION AT DIFFERENT DISTANCE}

After the lower protective seam is mined, the decreased stress will affect the gas release and flow of the protected seam. The stress relief regularity of the protected seam is different at different distances above the protective seam. The protective seam has been mined out, but the coal pillar that is $10 \mathrm{~m}$ wide was retained in the central zone of the working face. Monitoring points were arranged every five meters along the mining direction at different distances of $0 \mathrm{~m}, 2.5 \mathrm{~m}, 8 \mathrm{~m}, 11 \mathrm{~m}, 15 \mathrm{~m}, 17.8 \mathrm{~m}, 26 \mathrm{~m}$ and $40 \mathrm{~m}$ (Fig. 8). Figure 9 shows the stress distribution along the mining direction at different distances above the protective seam.

The stress distribution indicates that the gob of the protected seam is in the stress relief state, but the coal pillar's affected zone is in a highly concentrated stress state with values varying from $4 \mathrm{MPa}$ to $26 \mathrm{MPa}$. Figure 9 shows that the stress gradually decreases as the distance increases, and, accordingly, the stress curve also behaves differently. The peak value of the stress in the coal pillar's affected zone is approximately $26 \mathrm{MPa}$ (1.73 times the original stress) when the distance is $0 \mathrm{~m}$ while it is approximately $6 \mathrm{MPa}$ (0.83 times the original stress) when the distance is $26 \mathrm{~m}$. This suggests that the protected seam is completely in the stress relief state when the distance is greater than $26 \mathrm{~m}$. It means that the protected seam stress distribution is rarely affected by the coal pillar. Therefore, stress relief measures should be conducted when the interlayer distance 


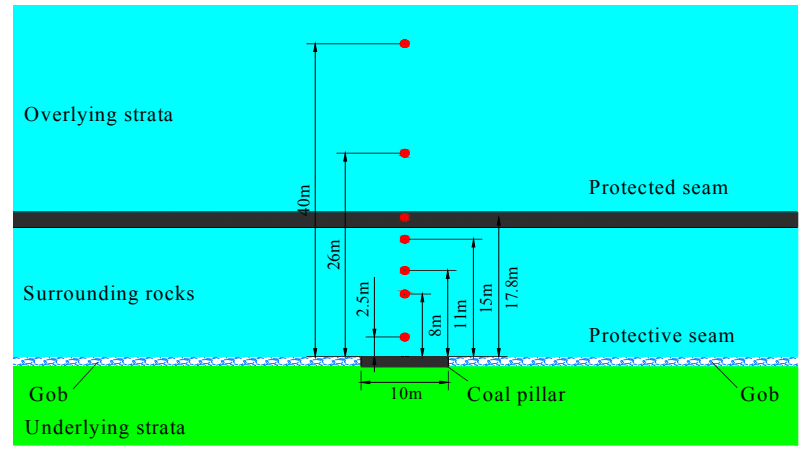

Fig. 8 Monitoring point arrangement along the $x-$ direction at different distances above the protective coal seam.

(a)

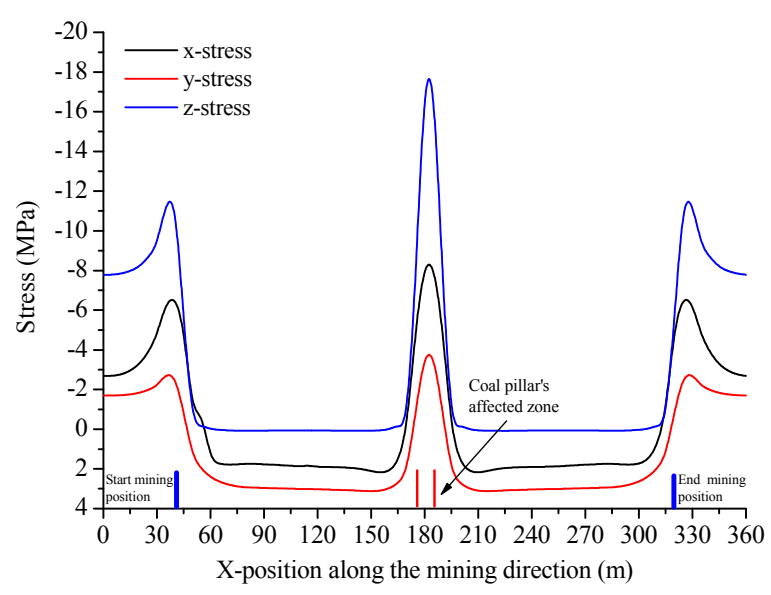

(c)

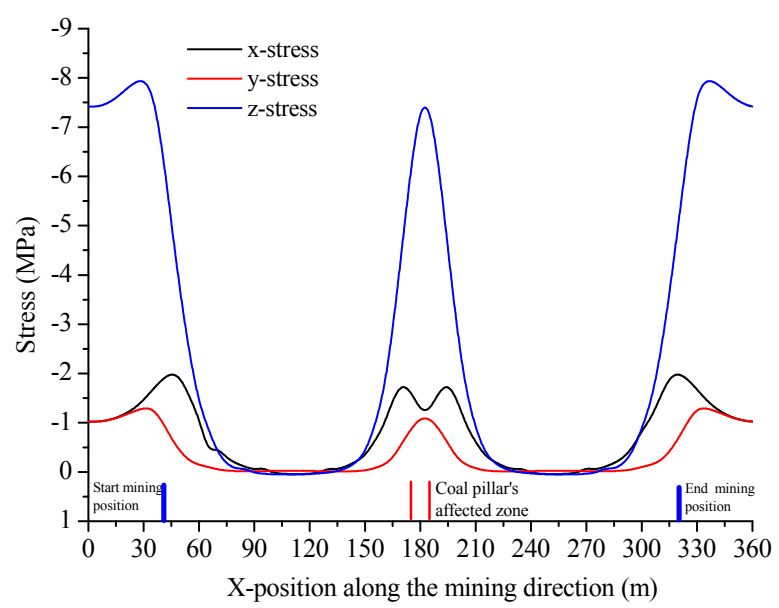

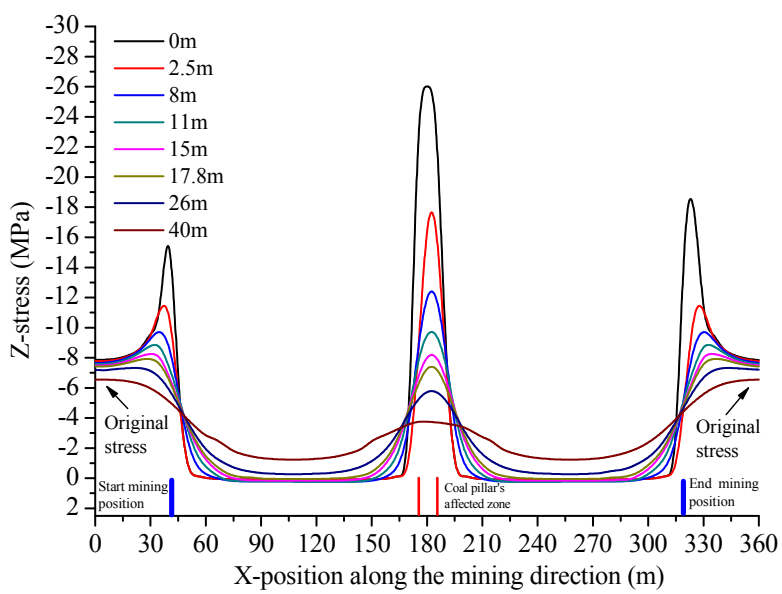

Fig. 9 Stress distribution along the $x$-direction at different distances above the protective seam.

(b)

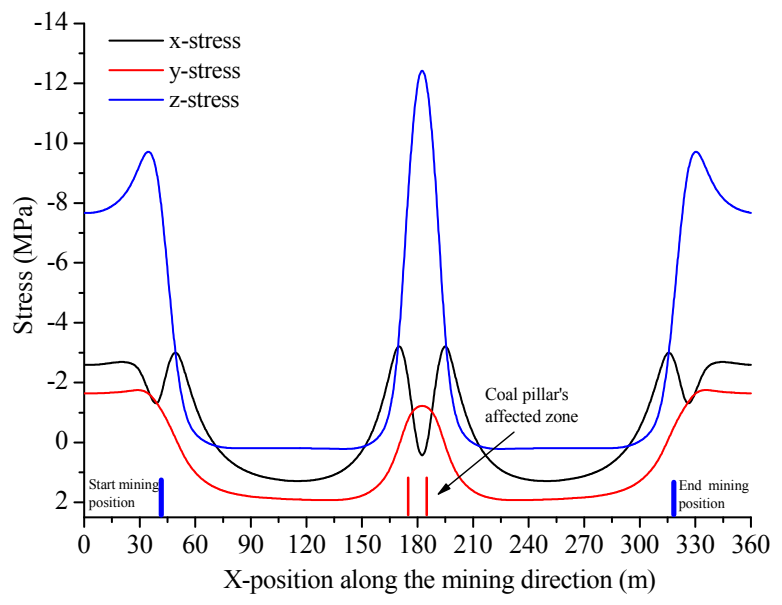

(d)

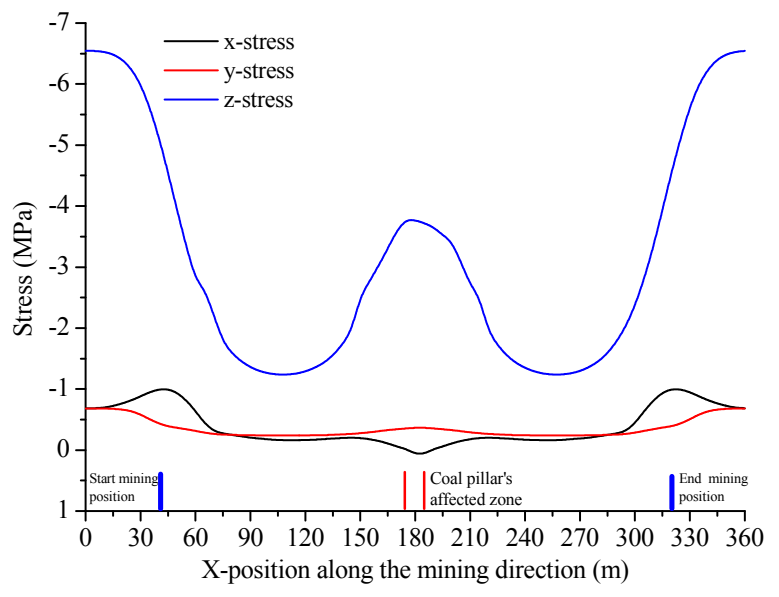

Fig. 10 Stress distribution along the x-direction at four different distances of (a) $2.5 \mathrm{~m}$, (b) $8 \mathrm{~m}$, (c) $17.8 \mathrm{~m}$ and (d) $26 \mathrm{~m}$ above the protective seam. 


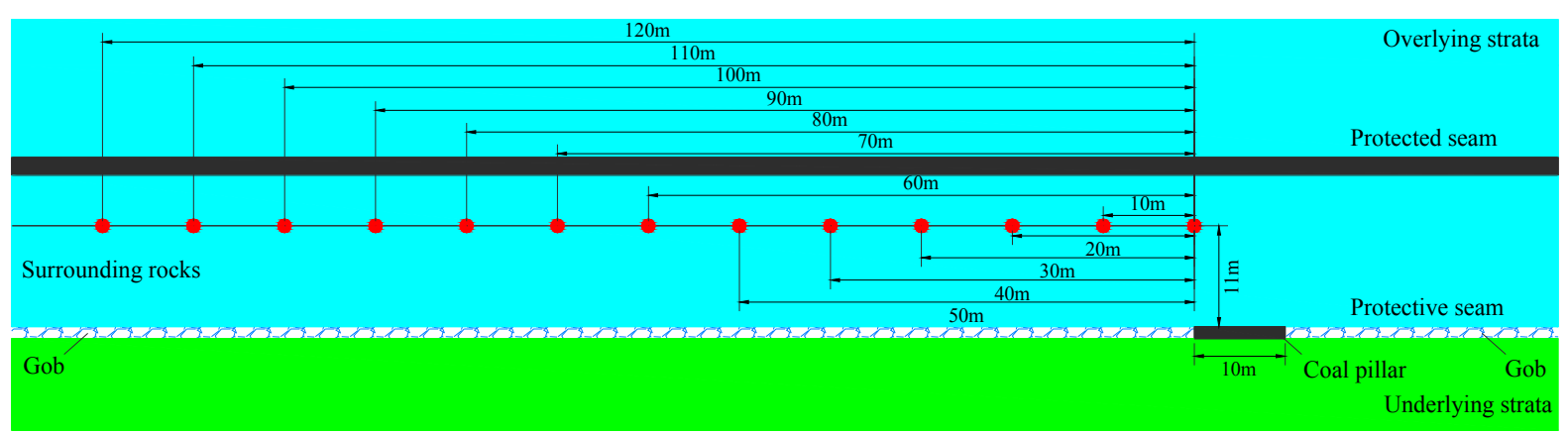

Fig. 11 Monitoring point arrangement at the distance of $11 \mathrm{~m}$ above the protective coal seam.

(a)

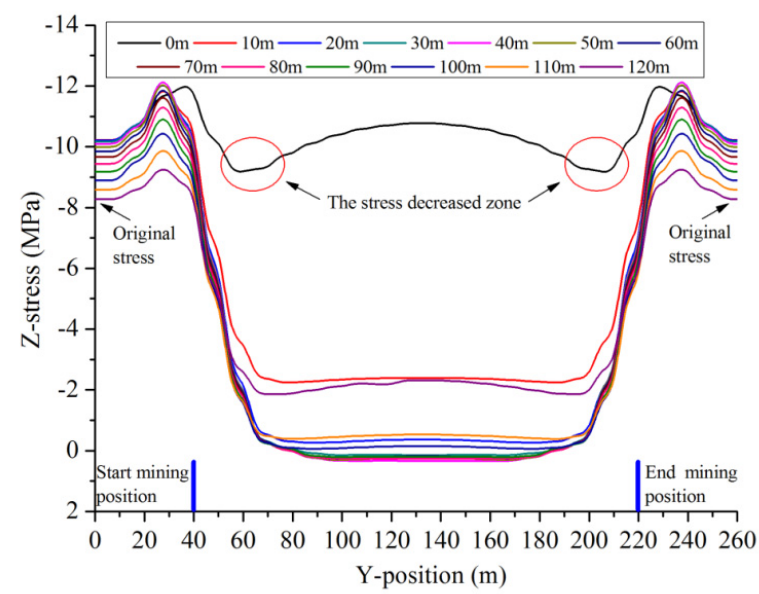

(b)

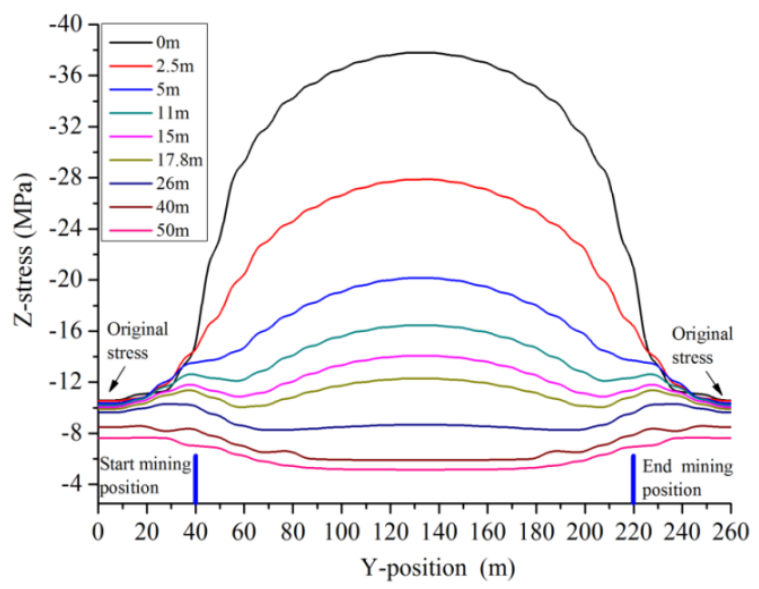

Fig. 12 (a)Vertical stress distribution along the y-direction at the distance of $11 \mathrm{~m}$ above the protective seam and (b) the vertical stress distribution along the y-direction at different distances above the protective seam.

between the protected seam and protective seam is less than $26 \mathrm{~m}$.

Figure 10 shows the three-dimensional stress distribution at different four distances of $2.5 \mathrm{~m}, 8 \mathrm{~m}$, $17.8 \mathrm{~m}$ and $26 \mathrm{~m}$ above the protective seam. The values of the $x$-stress, $y$-stress and $z$-stress both decrease as the distance increases. The three dimensional stress distribution curves of the coal pillar's affected zone appear as a single-peak when the distance is $2.5 \mathrm{~m}$ while only the $\mathrm{x}$-stress distribution curve changes a double-peak when the distance is $8 \mathrm{~m}$ and $17.8 \mathrm{~m}$. The peak values are 3.14 times, 2.29 times and 2.32 times the original stress, respectively, when the distance is $2.5 \mathrm{~m}$. However, the y-stress decreases to the peak value of $1.24 \mathrm{MPa}$ when the distance is $8 \mathrm{~m}$. This indicates that the $y$-stress begins to release, and then the gas will inrush into the roadways along the $y$-direction from the coal face. The concentrated stress factors of the $\mathrm{x}$-stress, $\mathrm{y}$-stress and z-stress are $0.08,0.54$ and 0.58 , respectively, when the distance is $26 \mathrm{~m}$. This shows that the protected seam working face is entirely in the stress relief state, and this is consistent with the above analysis.

\subsubsection{STRESS DISTRIBUTION ALONG Y-DIRECTION AT DIFFERENT DISTANCE}

Thirteen monitoring lines were arranged every ten meters along the y-position at the distance of $11 \mathrm{~m}$ above the protective seam (Fig. 11). Figure 12 (a) shows the vertical stress along the y-position at the distance of $11 \mathrm{~m}$ above the protective seam. When the distance is $0 \mathrm{~m}$ away from the coal pillar of the protective seam, it can be seen that the vertical stress varies from 9.17 MPa to $10.77 \mathrm{MPa}(0.9 \sim 1.05$ times the original stress). The two zones that vary from $50 \mathrm{~m}$ to $70 \mathrm{~m}$ and from $190 \mathrm{~m}$ to $210 \mathrm{~m}$ are decreased stress areas, which are favorable for gas drainage. The distribution of the decreased stress zone agrees with the O-shaped circle theory of methane enrichment (Xu, 1995). From the viewpoint of the threedimensional spatial location, the distribution of the decreased stress zone appears as a circle, which is near the roadway of the protected seam's working face. The gas easily flows or accumulates in the decreased stress zone. Therefore, boreholes for gas drainage should be drilled in the decreased stress circle in order to reduce or eliminate the outburst risk. The vertical stress decreases as the distance from the coal pillar of the protective seam increases. For instance, the vertical stress is in a compressive state 


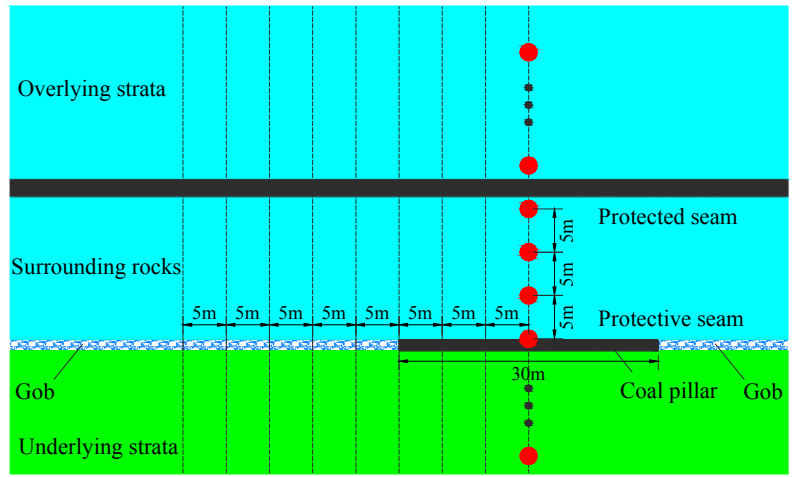

Fig. 13 Monitoring lines' arrangement along the zdirection.

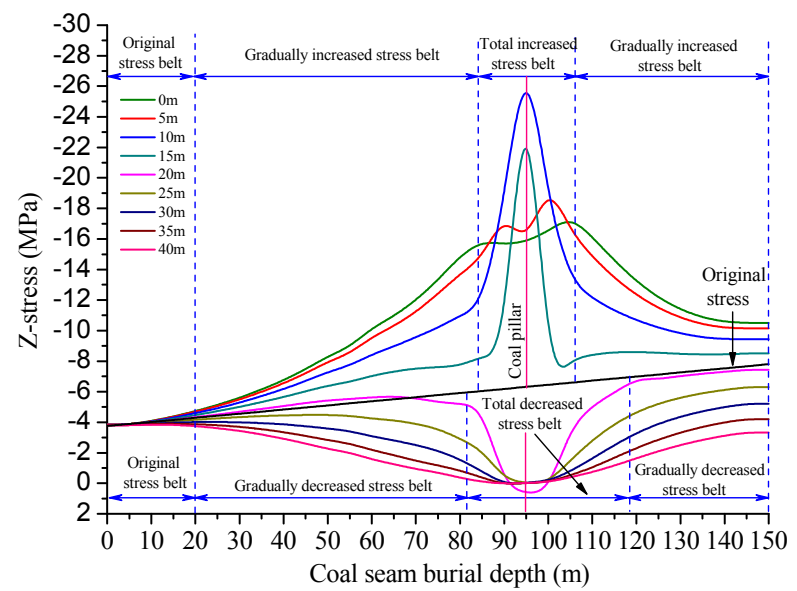

Fig. 14 Vertical stress distribution along the $\mathrm{z}$ direction at different distances away from the center of the coal pillar.

and the value drops to $2.28 \mathrm{MPa}$ when the distance is $10 \mathrm{~m}$ whereas the vertical stress changes from the compressive state to the tensile state at the minimum value of $0.21 \mathrm{MPa}$ when the distance is $80 \mathrm{~m}$. This explains that the zone that is affected by the highly concentrated stress is restricted to a limited area.

The vertical stress distributions along the y-position under the different distances of $0 \mathrm{~m}, 2.5 \mathrm{~m}$, $5 \mathrm{~m}, 11 \mathrm{~m}, 15 \mathrm{~m}, 17.8 \mathrm{~m}, 26 \mathrm{~m}, 40 \mathrm{~m}$ and $50 \mathrm{~m}$ are shown in Figure 12(b). The vertical stress distributions are symmetric. The stress decreases as the distance increases. The stress dramatically decreases as the distance increases from $0 \mathrm{~m}$ to $11 \mathrm{~m}$ and the maximum value drops from $37.8 \mathrm{MPa}$ to 16.46 $\mathrm{MPa}$. When the distance is $17.8 \mathrm{~m}$, the vertical stress reflects the original state. The vertical stress presents the stress relief state with the minimum value, which is lower than the original stress, when the distance is greater than $26 \mathrm{~m}$. This result agrees with the analysis of the stress distribution along the mining direction. Measures for stress relief such as hydraulic fracturing technology, carbon dioxide cracking technology and other methods should be used within $26 \mathrm{~m}$.

\subsubsection{STRESS DISTRIBUTION ALONG Z-DIRECTION AT DIFFERENT DISTANCE}

Monitoring lines for recording the vertical stress are arranged every five meters along the z-direction, as shown in Figure 13. There are nine monitoring lines in total that are used to study how the vertical stress distribution is affected by a $30 \mathrm{~m}$ wide coal pillar in the protective seam. Figure 14 shows the vertical stress distribution along the $\mathrm{z}$-direction at nine different distances of $0 \mathrm{~m}, 5 \mathrm{~m}, 10 \mathrm{~m}, 15 \mathrm{~m}, 20 \mathrm{~m}$, $25 \mathrm{~m}, 30 \mathrm{~m}, 35 \mathrm{~m}$ and $40 \mathrm{~m}$. When the distance is $0 \mathrm{~m}$, $5 \mathrm{~m}, 15 \mathrm{~m}$ and $20 \mathrm{~m}$, the vertical stress is in the stress concentrated state with the maximum value of $29 \mathrm{MPa}$. The vertical stress distribution has a doublepeak when the distance varies from $0 \mathrm{~m}$ to $5 \mathrm{~m}$ while it changes to a single-peak when the distance ranges from $10 \mathrm{~m}$ to $15 \mathrm{~m}$. Specifically, the highly concentrated stress distribution zone becomes broader but the peak value is lower when the distance is $10 \mathrm{~m}$ and $15 \mathrm{~m}$. The stress is in the stress relief state when the distance is larger than $20 \mathrm{~m}$. As the distance becomes greater, the stress relief zone also becomes wider.

The zone above the original stress line is called the increased stress zone while the zone under the original stress line can be called the decreased stress zone. When the distance is $0 \mathrm{~m}, 5 \mathrm{~m}, 10 \mathrm{~m}$ and $15 \mathrm{~m}$, the vertical stress is in the concentrated stress state and the value is significantly higher than the original stress. The zone that varies from $84 \mathrm{~m}$ to $107 \mathrm{~m}$ (from $-12 \mathrm{~m}$ in the floor to $11 \mathrm{~m}$ in the roof) is called the total increased stress belt. The vertical stress decreases gradually in the regions that vary from $20 \mathrm{~m}$ to $84 \mathrm{~m}$ and from $107 \mathrm{~m}$ to $150 \mathrm{~m}$ (from $11 \mathrm{~m}$ to $75 \mathrm{~m}$ in the roof and from $-12 \mathrm{~m}$ to $-55 \mathrm{~m}$ in the floor), and this region is called the gradually increased stress belt. The vertical stress is very close to the original stress from $0 \mathrm{~m}$ to $20 \mathrm{~m}$ (from $75 \mathrm{~m}$ to $95 \mathrm{~m}$ in the roof) along the z-direction, and this zone can be called the original stress belt.

When the distance is $20 \mathrm{~m}, 25 \mathrm{~m}, 30 \mathrm{~m}, 35 \mathrm{~m}$ and $40 \mathrm{~m}$, the vertical stress is in the stress relief state and the value is markedly lower than the original stress along the $\mathrm{z}$-direction in the zone that varies from $82 \mathrm{~m}$ to $118 \mathrm{~m}$ (from $-23 \mathrm{~m}$ in the floor to $13 \mathrm{~m}$ in the roof), which is called the decreased total stress belt. The vertical stress decreases gradually in the regions that vary from $20 \mathrm{~m}$ to $82 \mathrm{~m}$ and from $118 \mathrm{~m}$ to $150 \mathrm{~m}$ (from $13 \mathrm{~m}$ to $75 \mathrm{~m}$ in the roof and from $-23 \mathrm{~m}$ to $-55 \mathrm{~m}$ in the floor), and this zone can be defined as the gradually decreased stress belt. The original stress belt also varies from $0 \mathrm{~m}$ to $20 \mathrm{~m}$ (from $75 \mathrm{~m}$ to $95 \mathrm{~m}$ in the roof) along the z-direction. Boreholes should be comprehensively drilled in the decreased total stress region that varies from $13 \mathrm{~m}$ in the roof to $23 \mathrm{~m}$ in the floor for gas drainage when the distance is greater than $20 \mathrm{~m}$. 
Table 2 The original data of the boreholes for the 1801 working face.

\begin{tabular}{lccccc}
\hline $\begin{array}{c}\text { Borehole } \\
\text { number }\end{array}$ & $\begin{array}{c}\text { Dip angle } \\
\left({ }^{\circ}\right)\end{array}$ & $\begin{array}{c}\text { Sampling } \\
\text { depth }(\mathrm{m})\end{array}$ & $\begin{array}{c}\text { Gas content } \\
\left(\mathrm{m}^{3} / \mathrm{t}\right)\end{array}$ & $\begin{array}{c}\text { Gas flow } \\
\text { attenuation } \\
\text { coefficient }\left(\mathrm{d}^{-1}\right)\end{array}$ & Remarks \\
\hline 8.1 & 30 & 18.8 & 3.88 & 0.0523 & \\
8.2 & 25 & 19.7 & 4.75 & 0.0478 & \\
8.3 & 21 & 19.2 & 4.11 & 0.0585 & \\
8.4 & 36 & 17.5 & 4.81 & 0.0534 & \\
8.5 & 7 & 18 & 9.45 & 0.0236 & \\
8.6 & 5 & 20.5 & 8.49 & 0.01742 & In the collection process of the coal samples, three \\
8.7 & 18 & 16.5 & 12.32 & 0.0241 & outbursts occurred in the coal seam. \\
8.8 & 22 & 18.3 & 4.14 & 0.0559 & \\
8.9 & 12 & 20 & 4.37 & 0.0446 & \\
8.10 & 27 & 22.5 & 4.94 & 0.04254 & \\
8.11 & 30 & 18.5 & 5.32 & 0.0349 & \\
8.12 & 11 & 17 & 4.84 & 0.0313 & \\
\hline
\end{tabular}

\section{APPLICATION FOR METHANE CONTROL}

\subsection{IN SITU MEASUREMENT}

A field measurement program that consists of 12 boreholes was implemented in order to determine gas content and the gas flow attenuation coefficient in the Huahang coal mine. Measurement boreholes for the gas content and gas flow attenuation coefficient were arranged in 1801 haulage roadway of the 1801 working face. The distance between boreholes is $20 \mathrm{~m}$, and the coal sampling depth for the gas content measurement is greater than $15 \mathrm{~m}$. Following the Method of China University of Mining and Technology, the gas flow attenuation coefficient was determined using the direct measurement method. The original data of the boreholes is shown in Table 2. Based on the arrangement location, borehole numbers 8-5, 8-6 and 8-7 were arranged in coal pillar's affected zone. It can be seen that the maximum value of the gas content is $12.4832 \mathrm{~m}^{3} / \mathrm{t}$ while the minimum value is $3.3488 \mathrm{~m}^{3} / \mathrm{t}$. After the $\mathrm{C} 12$ coal seam was extracted, the outburst risk of the $\mathrm{C} 8$ coal seam was eliminated except in the coal pillar's affected zone. In the coal pillar's affected zone, the gas contents boreholes 8-5, $8-6$ and 8-7 had an average value of $10.3482 \mathrm{~m}^{3} / \mathrm{t}$, which is greater than $8 \mathrm{~m}^{3} / \mathrm{t}$. In the collecting process of the coal sample for borehole 8-7, three cannons occurred in coal seam. Regarding the gas flow attenuation coefficient, the average value of boreholes 8-5, 8-6 and 8-7 is $0.0217 \mathrm{~d}^{-1}$, which is smaller than that of other boreholes. Following the Regulations for the prevention and control of coal and gas outbursts, this indicates that the coal pillar's affected zone still has outburst risk. It is clear that the coal pillar significantly affects the protective effect of the protected seam. Highly concentrated stress, which was induced by the coal pillar, may indirectly influence the gas parameters such as the gas content, gas pressure and gas flow attenuation coefficient. Hence, we should take the coal pillar's affected zone as the key for methane control.

\subsection{DIVISIONAL MANAGEMENT IDEOLOGY FOR METHANE CONTROL}

Under multiseam mining, the coal seams with nonoutburst or lower outburst risks are first mined as the protective seam for the purpose of reducing or eliminating the higher outburst risk of the protected seam. After the protective seam is mined, the threedimensional stress will decrease in the decreased total stress belt. The gas of the protective seam will flow upward into the protected seam. In addition, the compressive affection of the gob may impel the storage gas into the coal face and then cause gas overruns in the protected seam working face. However, the gas is difficult to flow flowing in the coal pillar's affected zone, and then the gas pressure and gas content are relatively high. If improperly handled, coal and gas outbursts may happen. Therefore, the technological strategy for methane control must be studied according to the gas flow and enrichment behaviors in the protected seam mining process that is affected by the coal pillar of the protective seam.

Underground engineering is generally a complex dynamical system. In essence, a mining disaster is the coupled result of the occurrence of some disaster factors (Qiao, 2000). We proposed the divisional management strategy for methane control according to the stress distributions and gas flowing behaviors in different zones. Pertinent parameters should be comprehensively determined based on the numerical simulation results, field investigations and accumulated experiences according to the coalfield's practical conditions. The principle and technological methods are illustrated as follows.

(a) It should first adopt regional methane control and management measures such as protective seam mining or gas predrainage as keys, and then the partial methane control or management measures such as blasting technology and hydraulic fracturing technology can be used as supplements. It is 
imperative to adopt multiple measures for better methane control. The barrier pillar in the protective seam must be labeled in the mining engineering plan, and the coal pillar's affected zone must be determined according to the interlayer space and stress relief angle. Furthermore, the coal pillar's affected zone should be adjusted based on the dynamic changes of the methane flow behavior.

(b) The protected seam can be divided into the original stress zone, the stress relief zone and the highly concentrated stress zone along the striking trend of the working face. It is also divided into the total increased stress belt, the gradually increased stress belt and the original stress belt above the original stress line while it is divided into the total decreased stress belt, the gradually decreased stress belt and the original stress belt under the original line along the dipping trend. According to the respective feature of each zone, the divisional management strategy is proposed for methane control. The gas predrainage by using crossing boreholes and bedding boreholes should be mainly applied in the stress relief zone and the total decreased stress belt. Stress relief methods should be mainly used in the highly concentrated stress zone and the total increased stress belt first, and then applying the gas drainage to these zones.

(c) High level crossing boreholes which are located in the haulage roadway and the ventilation roadway of protective seam working face should be utilized for better gas drainage of the protective seam before it is mining. Boreholes had better located in the $\mathrm{O}-$ shaped circle distribution zone of protective seam and the distance should vary from $11 \mathrm{~m}$ to $20 \mathrm{~m}$ from the roadway of protected seam. The length and dip angle of the borehole should be adjusted according to the interlayer space. The sealing length of crossing boreholes should be greater than $5 \mathrm{~m}$ in order to achieve better drainage effect. The gas of the gob can be extracted by burying pipes in the mining process of protective seam and the burying pipe length should be about $12 \mathrm{~m}$ away from the roadway. The band length which is controlled by the bedding borehole ahead of the coal face should be greater than $60 \mathrm{~m}$, and the sealing length must be greater than $8 \mathrm{~m}$.

(d) Stress relief measures should be mainly implemented in the coal pillar's affected zone. The advanced distance should be greater than $20 \mathrm{~m}$ ahead of the coal face. The dense boreholes for gas extraction should be adopted to fully eliminate the effect of the coal pillar. In addition, some measures such as hydraulic fracturing technology and water injection technology may be also implemented. The implemented area of these measures should fully cover the coal pillar's affected zone. The border of coal pillar's affected zone can be determined by the stress relief angle varies from $56^{\circ}$ to $60^{\circ}$ according to the guideline of coal and gas outburst prevention (National Coal Mine Safety Supervision Bureau, 2013).

\subsection{FIELD APPLICATION OF TECHNOLOGICAL STRATEGIES}

The engineering practice for protective seam gas drainage and stress relief was conducted at the Huahang coal mine based on the guideline of technology strategy. The overall gas extraction and stress relief pattern can be summarized as Figure 15. To improve the gas control effect and completely eliminate the outburst risk of the protected seam, netlike crossing boreholes that were located in the roadways of protective seam were mainly taken into the application. Considering the coal pillar that was retained in the protective seam, a highly concentrated stress zone occurred in the protected seam. For the unprotected area, the dense boreholes for gas extraction and the large diameter boreholes for stress relief were adopted to fully eliminate the outburst risk of the protected seam. For the sake of preventing the released gas overrunning in the protected seam working face, bedding boreholes for gas drainage were also used. Furthermore, the gas of the gob was extracted by burying pipes. And the gas emission during the protected seam mining process was mainly solved by Y-shaped ventilation method.

\section{CONCLUSION}

This research aims at studying the stress redistribution and methane control of protected seam affected by the coal pillar of protective seam. It covers three following original aspects:

1. The coal pillar greatly affects the abutment stress distribution in the mining process of protected seam. It increases rapidly with the maximum value of 1.25 times the original stress when the coal face is in the central of the coal pillar's affected zone while it is in state of the stress relief in other zones. Boreholes for stress relief should be conducted more than $20 \mathrm{~m}$ ahead of the coal pillar's affected zone. When the coal face just enters and out of the coal pillar's affected zone, high gradient of the abutment stress easily breaks the coal seam, and then the methane easily flows into the working face, so the boreholes for gas drainage should be arranged in advance in order to avoid the gas overrunning in these two stages.

2. The O-shaped circle development zone is divided into two parts by the coal pillar and its development width is closely related to the protected seam mining stage and "three zones" developmental height especially the fractured zone. The maximum width of the O-shaped circle generally develops in the lower-middle part of the fractured zone. The stress distribution that is 
(a)

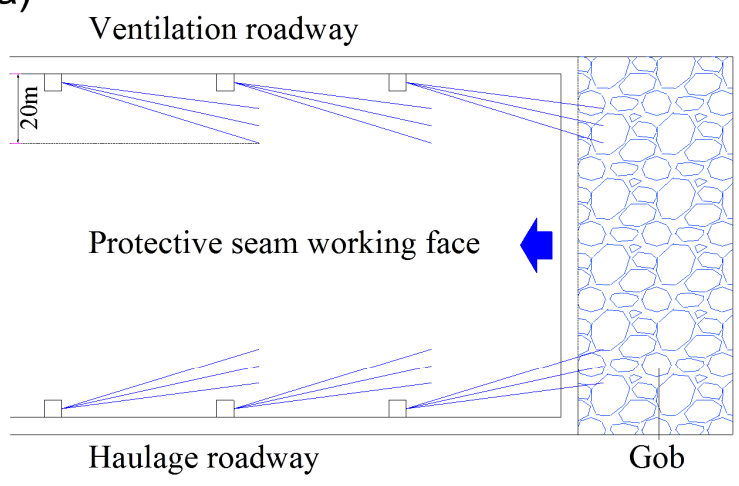

High level

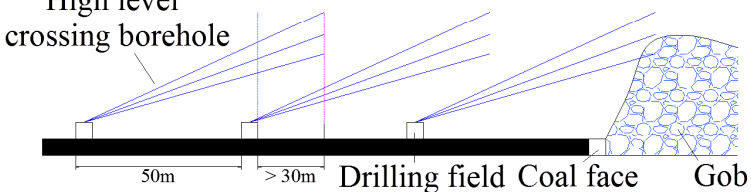

(b)

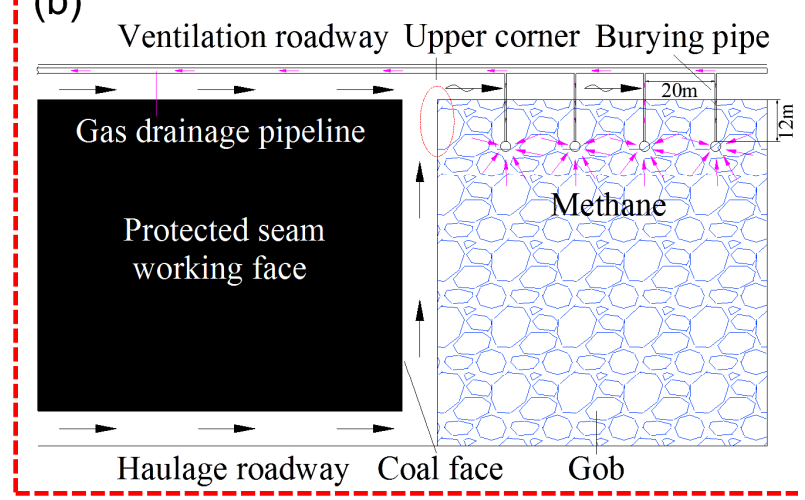

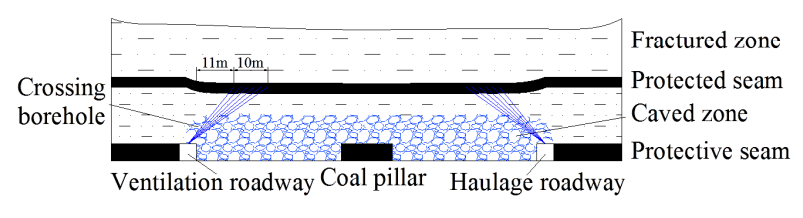

\section{(c)}

Ventilation $10 \mathrm{~m} \times 10 \mathrm{~m}$ Crossing boreholes $5 \mathrm{~m} \times 5 \mathrm{~m}$ Crossing boreholes roadway in the coal pillar affecting zone in the $\mathrm{O}$ shaped circle
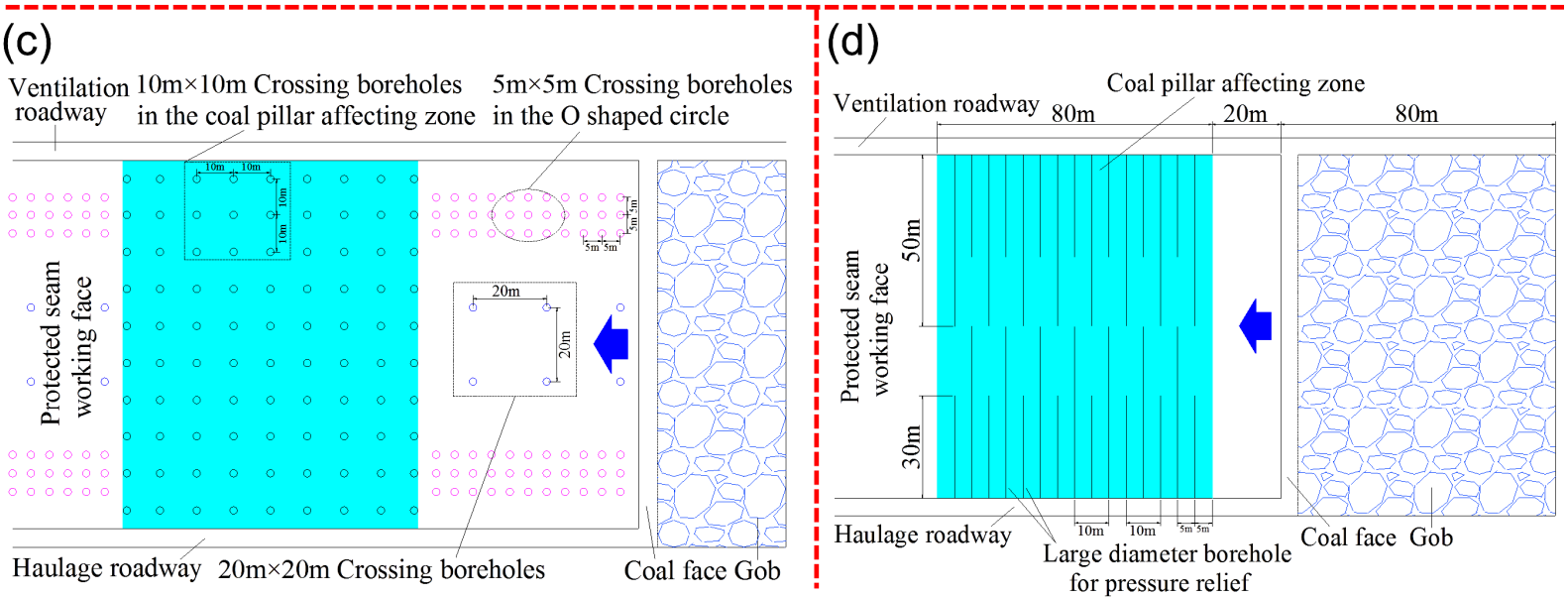

Fig. 15 Schematic diagram of gas drainage and stress relief in mining process of the protective seam: (a) high level crossing borehole arrangement, (b) gob burying pipe arrangement, (c) net-like crossing borehole arrangement and (d) large diameter boreholes arrangement for stress relief.

under the influence of the coal pillar is different when the distance above the protective seam is different. The stress distribution is little affected by the coal pillar when the distance is greater than $26 \mathrm{~m}$. The stress distribution along the vertical direction can be divided into total increased stress belt, the gradually increased stress belt and the original stress belt in the coal pillar's affected zone while it is divided into total decreased stress belt, the gradually decreased stress belt and the original stress belt in other zones. The boreholes should be located in the total increased stress belt and the total decreased stress belt for the purpose of stress relief and gas drainage.

3. We put forward the divisional management strategy for methane control according to the stress distribution and gas flowing behavior in different zones of the working face. The stress relief method is mainly used in the coal pillar's affected zone. The density of crossing boreholes for gas drainage should be greater in coal pillar's affected zone and the O-shaped circle while it can be smaller in other zones.

\section{ACKNOWLEDGEMENTS}

This study was supported by the National Natural Science Foundation of China (51574243), the Fundamental Research Funds for the Central Universities of China (2010YZ02) and Yue Qi Distinguished Scholar Project (80015Z1138). The author also thanks other researchers for their constructive suggestion and valuable assistance.

\section{REFERENCES}

Alireza, B. and Jing, L.: 2008, Stress effects on permeability in a fractured rock mass with correlated fracture length and aperture. Int. J. Rock Mech. Min. Sci., 45, 1320-1334. DOI: 10.1016/j.ijrmms.2008.01.015 
Ashok Jaiswal, Shrivastva, B.K.: 2009, Numerical Qiao, J.: 2000, On the preimages of parabolic periodic simulation of coal pillar strength. Int. J. Rock Mech. Min. Sci., 46, 779-788.

DOI: $10.1016 /$ j.ijrmms.2008.11.003

Bertuzzi, R., Douglas, K., Mostyn, G., Meynink, P.S., Road, D. and Ryde, N.: 2016, An approach to model the strength of coal pillars. Int. J. Rock Mech. Min. Sci., 89, 165-175. DOI: 10.1016/j.ijrmms.2016.09.003

Cheng, Y.M., Wang, J.A., Xie, G.X. and Wei, W.B.: 2010, Three-dimensional analysis of coal barrier pillars in tailgate area adjacent to the fully mechanized top caving mining face. Int. J. Rock Mech. Min. Sci., 47, 1372-1383. DOI: 10.1016/j.ijrmms.2010.08.008

Corthesy, R. and Leite, M.H.: 2008, A strain-softening numerical model of core discing and damage. Int. J. Wang, H., Jiang, Y. and Zhao, Y.: 2013, Numerical Rock Mech. Min. Sci., 45, 329-350. DOI: $10.1016 / j$. .jrmms.2007.05.005

Edelbro, C.: 2009, Numerical modelling of observed fallouts in hard rock masses using an instantaneous cohesionsoftening friction-hardening model. Tunn. Undergr. W Sp. Technol., 24, 398-409.

DOI: $10.1016 /$ j.tust.2008.11.004

Itasca consulting group: 2012, FlAC3D User's Guide.

Jayanthu, S., Singh, T.N. and Singh, D.P.: 2004, Stress distribution during extraction of pillars in a thick coal seam. Rock Mech. Rock Eng., 37, 171-192.

DOI: 10.1007/s00603-003-0003-2 points. Nonlinearity, 13, 813-818.

Sherizadeh, T. and Kulatilake, P.H.S.W.: 2016, Assessment of roof stability in a room and pillar coal mine in the U.S.using three-dimensional distinct element method. Tunn. Undergr. Sp. Technol., 59, 24-37. DOI: $10.1016 /$ j.tust.2016.06.005

Singh, A.K., Singh, R., Maiti, J., Kumar, R. and Mandal, P.K.: 2011, Assessment of mining induced stress development over coal pillars during depillaring. Int. J. Rock Mech. Min. Sci., 48, 805-818. DOI: $10.1016 /$ j.ijrmms.2011.04.004

Song, Z.: 2003, Applied underground mining pressure control. investigation of the dynamic mechanical state of a coal pillar during longwall mining panel extraction. Rock Mech. Rock Eng., 46, 5, 1211-1221. DOI: $10.1007 / \mathrm{s} 00603-012-0337-8$

Wilson, A.H.: 1983, The stability of underground workings in the soft rocks of the Coal Measures. Int. J. Min. Eng., 1, 91-187.

Xiong, Z., Wang, C., Zhang, N. and Tao, G.: 2015, A field investigation for overlying strata behaviour study during protective seam longwall overmining, Arab. J. Geosci., 8, 7797-7809. DOI: $10.1007 / \mathrm{s} 12517-015-1827-2$

Jiang, F., Wang, Y., Li, M. and Qu, Y.: 2017, Mechanism of Xu, J.: 1995, Gas drainage in the gob based on the feature of rockburst occurring in the protected coal seam induced by the coal pillar of the protective coal seam. Chinese J. Geotech. Eng., 39, 1689-1696. DOI: $10.11779 /$ CJGE201709017 $O$ shaped circle under influence of overlying strata movement. Min. Saf. 7, 1-4.

Xu, Y.: 1999, Coal mining technology. China University of Mining and Technology press.

Jin, K., Cheng, Y., Wang, W., Liu, H. and Liu, Z.: 2016, Yang, W., Lin, B., Yan, Q. and Zhai, C.: 2014, Stress Evaluation of the remote lower protective seam mining for coal mine gas control: A typical case study from the Zhuxianzhuang Coal Mine, Huaibei Coal field, China. J. Nat. Gas Sci. Eng., 33, 44-55. DOI: 10.1016/j.jngse.2016.05.004

Lee, Y. and Pietruszczak, S.: 2008, A new numerical procedure for elasto-plastic analysis of a circular opening excavated in a strain-softening rock mass. Tunn. Undergr. Sp. Technol., 23, 588-599. DOI: 10.1016/j.tust.2007.11.002

Li, J.: 2006, Technical manual for prevention of coal and gas outburst. China University of Mining and Technology press.

Min, K., Rutqvist, J., Tsang, C. and Jing, L.: 2004, Stressdependent permeability of fractured rock masses:a numerical study. Int. J. Rock Mech. Min. Sci., 41, 1191-1210. DOI: 10.1016/j.ijrmms.2004.05.005

National Coal Mine Safety Supervision Bureau: 2013, The stipulation for coal and gas outburst prevention. China redistribution of longwall mining stope and gas control of multi-layer coal seams. Int. J. Rock Mech. Min. Sci., 72, 8-15. DOI: 10.1016/j.ijrmms.2014.08.009

Yu, B., Zhang, Z., Kuang, T. and Liu, J.: 2016, Stress changes and deformation monitoring of longwall coal pillars located in weak ground. Rock Mech. Rock Eng., 49, 3293-3305. DOI: $10.1007 / \mathrm{s} 00603-016-0970-8$

Zhu, H., Liu, P., Chen, P. and Kang, J.: 2017, Analysis of coalbed methane occurrence in Shuicheng Coal field, southwestern China. J. Nat. Gas Sci. Eng., 47, 140153. DOI: $10.1016 /$ j.jngse.2017.09.003

Zhu, H., Liu, P. and Tong, Z.: 2014, Numerical simulation research and application on protected layer pressure relief affection under different coal pillar width. Procedia Eng., 84, 818-825. DOI: $10.1016 /$ j.proeng.2014.10.501 